\title{
Performan Ternak Entog Di Pedesaan Kecamatan Linggo Sari Baganti Kabupaten Pesisir Selatan Sumatera Barat
}

\author{
Khalil dan P.S. Yuspa \\ Jurusan Nutrisi dan Makanan Ternak, Fakultas Peternakan Universitas Andalas \\ Kampus Limau Manis, Padang
}

\begin{abstract}
The field survey was carried out to identify the most critical factors that influence the performances of muscovy duck raised extensively under village condition in sub district Linggo Sari Baganti, Pesisir Selatan, West Sumatra. Thirty-three muscovy duck farmers, which were distributed in 4 villages in the sub district, were selected and interviewed. Information collected included: flock size, egg production, egg hatchability, mortality, daily management practices, feed and feeding and health control. The average number of muscovy ducks raised was 11 ducks/farmer. The ducks laid egg 2-3 times per year with the average number of 12 eggs/duck/laying period. The hatchability of egg was about 84 $\%$, but the mortality of young duck during starter period was found very high, i.e. $42 \%$. Although about $67 \%$ gave supplemented feed for their ducks, most of the feed consumed by the ducks were originated from scavenging. Most of farmers (70\%) did not take care young ducks. The ducklings were let to scavenge with their mother for about 12 weeks of old. Such feeding and management practices might be the major causing factors for the low egg production and high mortality of young duck.
\end{abstract}

Key words: muscovy duck, extensively, nutrition.

\section{Pendahuluan}

Kecamatan Linggo Sari Baganti merupakan salah satu dari sebelas kecamatan yang ada di Kabupaten Pesisir Selatan, Sumatera Barat. Penduduk berjumlah sekitar 38.178 jiwa atau 8.667 kepala keluarga yang tersebar di 12 desa dengan mata pencaharian utama berupa usaha tani (tanaman pangan), ternak dan nelayan. Ternak yang populer dipelihara adalah sapi, yang terkenal dengan sapi pesisir. Jenis ternak lain seperti kerbau, ayam buras, itik (petelur) dan entog umumnya dipelihara dalam skala kecil sebagai usaha sambilan (BPS Dati. II Pesisir Selatan 1999).

Entog (Cairina moschata) atau dikenal dengan muscovy duck atau itik Manila merupakan ternak unggas yang sudah biasa dipelihara peternak di pedesaan, tetapi perkembangbiakan dan kontribusinya secara ekonomis masih terbatas, jika dibandingkan dengan ayam buras dan itik petelur. Ternak ini masih mendapat perhatian yang sangat terbatas baik oleh peternak yang memeliharanya maupun oleh instansi terkait. Hal ini diduga karena potensi ternak entog masih belum banyak diketahui dan peternak menganggap bahwa entog dapat berkembang biak tanpa membutuhkan banyak perhatian dari peternak.

Entog menghasilkan karkas yang mengandung kadar lemak rendah (Hetzel, 1986). Kualitas karkas entog meningkat sejalan dengan meningkatnya umur (Leclercq dan De Carville, 1986). Di Perancis daging entog akhir-akhir ini menjadi lebih 
populer terutama bagi konsumen yang cenderung memilih karkas yang mengandung lemak rendah (Leclercq dan De Carville, 1986).

Di Indonesia potensi entog mulai dikenal untuk penghasil daging unggas yang sehat dengan cara menyilangkan itik petelur dengan entog, yang dikenal dengan Tiktok (mule duck) (Kompas, 2002). Di Sumatera Barat, telur entog mulai banyak digemari masyarakat untuk dicampur dengan minuman teh atau kopi yang dikenal dengan minuman teh atau kopi telur, karena rasanya lebih nikmat dan diyakini berkhasiat. Sedangkan daging entok biasa dimasak dengan santan kelapa dan cabe muda, yang terkenal dengan gulai itik hijau Koto Gadang .

Dari aspek pakan dan nutrisi, entog sangat efisien dalam penggunaan makanan. Entog dikenal sebagai pemakan hijauan dan dapat mengkonsumsi pakan yang mengandung serat tinggi, seperti rumput dan hijauan lainnya (Holderread, 1983; Edwards et al., 1986). Bedasarkan hasil penelitian Khalil (1989) entog dapat menggunakan pakan yang mengandung serat tinggi dan rendah protein dan energi secara effisien, terutama setelah periode starter.

Keunggulan lain ternak entog jika dibanding jenis itik atau unggas lainnya adalah: lebih tahan terhadap penyakit, tidak menimbulkan suara gaduh, dapat hidup di daerah kering maupun basah, mempunyai sifat mengeram dan pelindung anak yang baik (Little et al., 1992).

Penelitian ini dilakukan dengan tujuan untuk mengidentifikasi faktor yang sangat berpengaruh dari aspek pengelolaan dan pemberian pakan terhadap performan ternak entog (produksi telur dan mortalitas) yang dipelihara secara ekstensif di daerah pedesaan kecamatan Linggo Sari Baganti Kabupaten Pesisir Selatan.

\section{Materi Dan Metode}

Penelitian dilakukan melalui survey lapangan (rapid rural appraisal) dan dimulai pada tanggal 30 Oktober sampai 7 Desember 2001. Pada tahap pertama dilakukan pengumpulan data sekunder sebagai pedoman untuk penetapan lokasi (desa) penelitian dan responden yang akan diwawancarai. Data sekunder yang dikumpulkan meliputi: jumlah KK yang memelihara entog, populasi entog dan kondisi geografis Kecamatan Linggo Sari Baganti secara umum. Data ini diperoleh dari kantor kelurahan, kecamatan, dinas pertanian dan instansi terkait lainnya.

\section{Penetapan Lokasi}

Kecamatan Linggo Sari Baganti terdiri atas 12 desa. Untuk lokasi penelitian dipilih 4 desa berdasarkan populasi entog, jumlah kepala keluarga (KK) yang memelihara entog dan kemudahan dijangkau. $\mathrm{Ke}-4$ desa yang tepilih adalah Desa Punggasan Utara, Punggasan Timur, Air Haji Tengah dan Air Haji Barat.

\section{Penetapan Responden}

Responden dipilih sebanyak 30 $\%$ dari jumlah total $\mathrm{KK}$ yang memelihara ternak entog. Penetapan responden didasarkan pada syaratsyarat tertentu (purposive sampling) (Singarimbun dan Effendi, 1989), yaitu peternak yang memiliki minimal 5 (lima) ekor entog. Jumlah total repsponden terpilih adalah $33 \mathrm{KK}$, dengan rincian setiap desa disajikan pada Tabel 1.

Sebagian besar responden $(72$ $\%)$ terpilih berumur antara 25-55 tahun, dengan tingkat pendidikan 
terbanyak adalah sekolah dasar ( $85 \%)$ dan pekerjaan utama bertani ( $42 \%)$ dan ibu rumah tangga (55\%) (Tabel 2).

\section{Pengumpulan Data Primer}

Pada tahap kedua dilakukan pengumpulan data dari peternak yang terpilih sebagai responden. Pengumpulan data dilakukan dengan bantuan daftar pertanyaan yang telah dipersiapkan sebelumnya melalui pengamatan langsung dan wawancara dengan peternak. Data atau informasi yang dikumpulkan meliputi: skala usaha (induk, dara, anak), sistim pemeliharaan (manajemen harian, bibit, kandang, penanggulangan penyakit dan kendala), jenis pakan dan cara pemberiannya (jenis pakan yang diberikan oleh peternak dan pakan yang dicari sendiri oleh ternak, cara pemberian dan memperoleh pakan), kualitas bahan pakan (contoh bahan diambil untuk dianalisa), performan entog (jumlah telur, daya tetas dan mortalitas) dan latar belakang responden (umur, pendidikan dan mata pencaharian utama).

\section{Analisis Data}

Data hasil penelitian dianalisa secara statistik dengan menghitungnya dalam bentuk persentase.

Tabel 1. Rincian Jumlah Penduduk, KK, Peternak Entog dan Responden yang Dipilih di 4 Desa Penelitian Kecamatan Linggo Sari Baganti

\begin{tabular}{lcccc}
\hline Nama Desa & $\begin{array}{c}\text { Jumlah } \\
\text { Penduduk } \\
\text { (orang) }\end{array}$ & Jumlah KK & $\begin{array}{c}\text { Jumlah } \\
\text { Peternak Entog } \\
\text { (KK) }\end{array}$ & $\begin{array}{c}\text { Jumlah } \\
\text { Responden } \\
\text { (KK) }\end{array}$ \\
\hline Punggasan Utara & 3289 & 761 & 50 & 15 \\
Punggasan Timur & 3602 & 769 & 22 & 7 \\
Air Haji Tengah & 4080 & 988 & 19 & 6 \\
Air Haji Barat & 4122 & 1088 & 17 & 5 \\
\hline Jumlah & 15093 & 3606 & 108 & 33 \\
\hline
\end{tabular}

Tabel 2. Latar Belakang Responden Berdasarkan Umur, Pendidikan dan Pekerjaan Utama

\begin{tabular}{ccc}
\hline$\quad$ Parameter & Jumlah (orang) & $\%$ \\
\hline Umur: & 1 & \\
\hline$-\quad<25$ tahun & 24 & 3,0 \\
$-\quad 25-55$ tahun & 8 & 72,7 \\
$-\quad>55$ tahun & 16 & 24,2 \\
\hline Pendidikan: & 12 & 48,5 \\
\hline - Tidak tamat SD & 2 & 36,4 \\
- SD & 3 & 6,1 \\
- SLTP & - & 9,1 \\
- SLTA & & - \\
\hline PT & 14 & 42,4 \\
\hline - Tani & 1 & 3,0 \\
- Pegawai & 18 & 54,5 \\
\hline - Rumah tangga & &
\end{tabular}




\section{Hasil Dan Pembahasan}

Hasil penelitan menunjukkan bahwa jumlah ternak entog yang dipelihara rata - rata 11 ekor per responden. Entog bertelur 2-3 kali per tahun dengan jumlah telur rata - rata 12 butir per periode bertelur atau sekitar 25-35 butir per tahun. Meskipun daya tetas telur mencapai $84 \%$, tetapi angka kematian anak cukup tinggi, mencapai $42 \%$.

Kematian anak banyak terjadi pada umur 4 minggu pertama. Berdasarkan informasi dari peternak, kematian anak cukup tinggi bukan disebabkan oleh serangan penyakit. Hanya sekitar $21 \%$ peternak yang berusaha mengurung anak setelah menetas bersama induk selama 1-3 minggu. Selama dikurung entog diberi pakan berupa ransum ayam. Sebagain besar peternak $(70 \%)$ tidak memberikan perlakuan khusus terhadap anak entog yang baru menetas. Setelah menetas anak langsung dilepas bersama induk untuk mencari makan sendiri. Penyebab kematian yang paling umum adalah predator, yang diakui oleh $37 \%$ responden. Penyebab lain dari kematian anak antara lain: keracunan (24\%), terinjak induk (3 $\%)$ dan kedinginan (10\%).

Sekitar $26 \%$ responden mengaku tidak mengetahui penyebab kematian anak. Hal ini menunjukkan bahwa masih banyak peternak yang memelihara entog yang kurang memberi perhatian kepada anak entog yang masih lemah untuk dibiarkan mencari makan sendiri, meskipun induk entog terkenal dengan kemampuannya yang baik memelihara anak (good mothering). Pada umur di bawah 4 minggu, pertumbuhan bulu belum sempurna, anak masih lemah secara fisik dan mengalami kekurangan gizi, sehingga anak tidak mampu mengikuti induknya, mudah diserang predator, tidak tahan perubahan cuaca.

Kurangnya perhatian peternak terhadap anak entog ini diduga terkait dengan terbatasnya kualitas sumberdaya peternak, fasilitas kandang dan ketersediaan pakan. Sebagian besar responden $(85 \%)$ berpendidikan sekolah dasar, seperti yang terlihat pada Tabel 2. Meskipun $72 \%$ responden dalam usia produktif (25-55 tahun), tetapi pendidikan yang terbatas mempengaruhi sikap dan kemampuan mereka dalam mengelola dan mengembangkan usaha.

Sebagian besar peternak menyediakan kandang untuk entog, tetapi kandang umumnya dibangun seadanya, kurang memperhatikan aspek kenyamanan dan kesehatan, Kandang ditempatkan di belakang rumah (45 $\%)$, di kolong rumah (27\%) atau di samping rumah $(24 \%)$. Hanya $3 \%$ peternak yang tidak menyediakan kandang untuk entog. Kandang umumnya dibangun tanpa dilengkapi ruang khusus untuk anak, tempat bertelur (nest) dan tempat makan dan minum. Kandang umumnya hanya digunakan pada malam hari dan pada waktu entog mengerami telur, kecuali pada musim padi mulai ditanam dan saat padi mulai berbulir sampai dipanen, dimana semua ternak unggas harus dikurung selama 24 jam.

Sebagain besar kebutuhan makanan dipenuhi oleh ternak dengan mencari makan sendiri, dengan cara melepas ternak sepanjang hari (scavenging). Berdasarkan pengamatan peternak, jenis pakan yang banyak dikonsumsi ternak entog antara lain: ikan - ikan kecil, keong mas, bekicot dan cacing, daun ubi kayu, daun talas, rumput dan enceng gondok. Makanan ini diperoleh dari selokan, kali dan lahan disekitar pekarangan. 
Sebagian besar peternak ( $85 \%)$ mengaku memberikan makanan tambahan kepada entog, akan tetapi pemberiannya tidak teratur dan tergantung pada ketersediaan pakan. Peternak juga tidak membedakan jenis pakan yang diberikan untuk anak dan entog dewasa. Pakan yang umum diberikan berupa sisa dapur seperti nasi sisa dan kepala ikan atau bahan yang tersedia di pekarangan seperti ubi kayu atau yang dapat dibeli di warung, seperti ransum ayam. Pada Tabel 3 disajikan jenis pakan yang biasa diberikan kepada entog.

Jika diperhatikan dari aspek kualitas, makanan yang dicari sendiri dan yang diberikan oleh peternak mempunyai nilai nutrisi yang cukup baik. Sumber protein hewani berasal dari ikan kecil, bekicot, cacing dan keong mas, dengan kandungan dan kualitas protein yang sangat baik. Sebagai sumber vitamin berasal dari rumput, daun ubi kayu dan daun talas. Sedangkan sumber energi diperoleh dari dedak, ampas kelapa, empulur sagu dan eceng gondok. Akan tetapi, dari segi jumlah, makanan yang dikonsumsi diyakini masih belum dapat memenuhi kebutuhan ternak. Hasil penelitian Tadelle et al. (2002) pada ternak ayam menunjukkan bahwa ayam yang biasa mencari makan sendiri secara scavenging biasanya mengalami defisiensi protein, kalsium dan pospor. Menurut
Wiseman (1987) entog jantan dan betina umur 1-12 minggu membutuhkan ransum masing - masing sekitar 145 dan 95 gram per ekor per hari dengan kandungan protein 14-16 $\%$ dan energi $2600-3000 \mathrm{kkal} \mathrm{ME} / \mathrm{kg}$.

Disamping itu, ternak banyak menghabiskan energi yang dikonsumsinya dengan berkeliaran sepanjang hari untuk mencari makan. Hal ini merupakan salah satu penyebab utama rendahnya produksi telur, yang hanya mencapai rata - rata 12 butir per periode bertelur. Disamping itu, induk harus mengasuh anak sampai umur 3-4 bulan, sebelum disapih, sehingga entog hanya dapat bertelur 2-3 kali per tahun, dengan total produksi telur sekitar 25-25 butir per tahun.

Hasil penelitian juga membuktikan bahwa ternak entog termasuk jenis ternak unggas yang jarang mehadapi masalah penyakit (Holderread, 1983; Basuno et al. 1985, Khalil, 1989, Bintang, 2000). Meskipun entog dilepas sepanjang hari, kematian induk jarang ditemui. Informasi dari responden menunjukkan bahwa tidak ditemukan adanya penyakit menular atau yang berakibat fatal pada entog, seperti penyakit ND (new castle diseases) pada ayam. Tidak ditemukan upaya khusus yang dilakukan peternak untuk mencegah serangan penyakit, seperti vaksinasi.

Tabel 3. Jenis Pakan yang Biasa diberikan Peternak kepada Entog di Kecamatan Linggo Sari Baganti, Kabupaten Pesisir Selatan

\begin{tabular}{ll}
\hline \multicolumn{1}{c}{ Kelompok } & \multicolumn{1}{c}{ Nama bahan } \\
\hline Sumber energi & $\begin{array}{l}\text { Dedak padi, nasi sisa, empulur sagu, } \\
\text { jagung Dan ubi kayu } \\
\text { Ransum ayam komersial, kepala ikan, } \\
\text { ampas kelapa, bungkil kelapa }\end{array}$ \\
\hline
\end{tabular}


Peternak hanya mengandalkan ke-mampuan daya tahan entog terhadap serangan penyakit. Jika ada entog dewasa yang mati, kematian ini umumnya disebabkan karena keracunan. Kematian entog dan juga itik petelur dewasa sering terjadi akibat keracunan bakteri botulism karena mengkonsumsi bangkai binatang atau sisa tanaman yang membusuk (Holderread, 1983; Evans dan Setioko, 1997).

\section{Kesimpulan}

Ternak entog mampu beradaptasi dengan lingkungan pedesaan dan sistim pengelolaan yang minimum. Akan tetapi karena pakan yang dikonsumsinya belum memenuhi kebutuhan dan pengelolaan anak belum dilakukan secara optimal maka produksi telur per tahun masih rendah dan angka kematian anak masih tinggi. Oleh karena itu melalui perbaikan pakan dan pengelolaan anak diharapkan dapat meningkatkan produktifitas dan mengurangi angka kematian anak entog yang dipelihara secara ekstensif.

\section{Daftar Pustaka}

Basuno, E., A.R. Setioko dan R.E. Abdelsamie, 1985. Survey Itik Manila di Desa Pandan Sari, Ciawi, Bogor. Ringkasan Laporan Hasil Penelitian BALITNAK, Ciawi, Bogor.

Bintang, I.A.K., 2000. Performan anak entog dengan berbagai pola pemeliharaan. Jurnal Peternakan dan Lingkungan, Fakultas Peternakan Universitas Andalas.

Biro Pusat Statistik, 1999. Kabupaten Pesisir Selatan dalam Angka, BPS Dati II Pesisir Selatan.
Edwards, P., E.W. McCoy, Ch. Pacharaprakiti, K. Kaepaitoon, D. Little, S. Sirichanthoon, S. Pramualkija, M. Yomjinda and S. Lim., 1986. Buffalo/fish and duck/fish integrated systems for small-scale farmers at the family level. AIT Res. Rep. No. 198. AIT, Bangkok.

Evans, A.J. and A.R. Setioko, 1997. Traditional systems of layer flock management in Indonesia. In: Duck Production, Science and World Pracrice. Edditors: D.J. Farrel and P. Stapleton. University of New England, Armidale, Australia, pp. 306322.

Hetzel, D.J.S, 1986. Domestic ducks: an historical perspective. In: Duck Production, Science and World Pracrice. Edditors: D.J. Farrel and P. Stapleton. University of New England, Armidale, Australia, pp. 1-5.

Holderread, D., 1983. Raising the Home Duck Flock. Garden Way Publishing, Oregon.

Khalil, 1989. Development of feeding systems for muscovy duck and some implications for integrated farming. Master Thesis. AIT, Bangkok.

Kompas, 2002. Tiktok, sumber protein sehat. Harian umum Kompas, Edisi 5 Maret 2002, hal. 10.

Lerclerq, B and H. De Carville, 1986. Growth and body composition of muscovy ducks. In: Duck Production, Science and World Pracrice. Edditors: D.J. Farrel and P. Stapleton. University of New England, Armidale, Australia, pp. 102-109. 
Little, D.C, Khalil and P. Takaekaew, 1992. Development of duckfish integrated systems in Northeast Thailand. Proc. of the sixth AAAP Animal Sci. Congress, Vol. II: 93-106.

Singarimbun dan S. Effendi, 1989. Metode Penelitian Survey. LP3ES, Jakarta.
Tadelle, D., D. Nigusie, Y. Alemu and K.J. Peters, 2002. The feed resource base and its potentials for increased poultry production in Ethiopia. World Poult.Sci., 58:77-87.

Wiseman, J., 1987. Feeding of Nonruminant Livestock. Butterworth, Nottingham.

Alamat Korespondensi: Dr. Ir.Khalil, M.Sc.

J1. Raya Padang Panjang-Bukittinggi Km. 09

Simpang Koto Tinggi, Pandai Sikek

Padang Panjang 27251

Telp/Fax: 0752/498162

HP: 08126611691

Artikel diterima 30 Septembar 2006, disetujui 10 Oktober 2006 